\title{
AOR
}

Selected Papers of \#AolR2020:

The 22nd Annual Conference of the

Association of Internet Researchers

Virtual Event / 13-16 Oct 2021

\section{A REPERTOIRE OF EVERYDAY RESISTANCE AND TECHNOLOGICAL (IN)SECURITY: CONSTRUCTING THE ROHINGYA DIASPORA AND TRANSNATIONAL IDENTITY POLITICS ON SOCIAL MEDIA}

Abdul Aziz

Digital Media Research Centre, Queensland University of Technology, Australia

\section{Extended Abstract}

Digital technologies have allowed migrants and diaspora to ascertain and revive their 'diasporic imaginaries' (Georgiou, 2006, 2019) and led to the rise of emerging digital diasporic networks on transnational spaces (Levitt \& Schiller 2004). As illustrated by Anderson's (2006) concept of "imagined communities" and Hall's (1990) insights into diaspora and cultural identity formation, examining diasporic and transnational networks have been critical in developing media and communication studies (Ponzanesi, 2020). Additionally, Appadurai's (1996) term of "scapes" has been useful to understand transnational identities and how cultural transformation is intertwined with changing digital communication landscapes.

This research examines how social media is used to negotiate identity politics, as well as how online narratives contribute to Rohingya transnational identity. The Rohingya, known as the 'most persecuted minority in the world', is an ethnic minority group of Myanmar who has been forcefully made stateless through constant and ongoing systemic and institutionalised persecution by the Burmese government. In this context, transnational networks of Rohingya diaspora groups have campaigned to recognise their sufferings and citizenship rights in global advocacy forums (e.g., Bernal, 2014, Brinkerhoff, 2009) using social media during and after 'genocide' in Rakhine state in 2017. Yet, the use of such technologies like social media also poses security threats.

This paper mainly draws on literature of digital media and internet studies within forced migration, transnationalism and diaspora contexts. In digital migration studies (Leurs \& Smets, 2018), research has made significant strides in understanding refugees' media practices during the migration, transnational family ties, settlement in a host society (e.g., Alencar, Kondova, \& Ribbens, 2019; Kaufmann, 2018; Robertson, Wilding, \& Gifford, 2016). However, little attention has been paid to more nuanced understanding everyday (digital) resistance and identity negotiation through social media practice in Suggested Citation (APA): Aziz, A. (2021, October). A repertoire of everyday resistance and technological (in)security: Constructing the Rohingya diaspora and transnational identity politics on social media. Paper presented at AolR 2021: The 22nd Annual Conference of the Association of Internet Researchers. Virtual Event: AolR. Retrieved from http://spir.aoir.org. 
the context of conflict and forced migration. Additionally, very few studies (Abraham \& Jaehn, 2019; Al-Rawi, 2019) show digital media use of the Rohingya community, and no study, to date, highlights how they negotiate their identity in a way that articulates their transnational engagement for justice and citizenship rights. To situate the conceptualisation of everyday digital media practices in diasporic settings, I use Scott's (1985) concept of "everyday forms of resistance" with a combination of Goffman's (1959) work on self-representation. The question of identity politics and resistance is explored more precisely through the lens of power structures as Foucault argued "where there is power, there is resistance" $(1978,95-96)$.

This study follows the idea of multi-sited approach (Marcus, 1995) to acknowledge the 'methodological transnationalism' (Amelina \& Faist, 2012) paradigm in migration studies, to go beyond nation state as a unite of analysis. In doing so, this study draws on a qualitative approach of semi-structured interviews (Kvale \& Brinkmann, 2009) and social media scroll back interviews (Robards \& Lincoln, 2019) methods to investigate the use of technologies in their everyday experiences of prolonged displacement in the Cox's Bazar refugee camp, Bangladesh and among resettled refugees in Brisbane, Australia, both distinct but interconnected within a power structure. Face to face interviews $(n=20)$ were conducted in Brisbane, while mobile/online interviews $(n=10)$ were followed to collect data from the Cox's bazar refugee camp.

The findings offer some new insights into the lived experience with technology and how participants negotiate using social media to form a community while also enables us to shed light on a larger context dealing with issues of surveillance and insecurity.

Although most participants see technologies have been a lifeline for their survival, some participants from the Cox's Bazar refugee camps show that surveillance has also been key concern in everyday life, thus how they negotiate their identity to avoid harassment and intimidation in the camps. The findings shows that repertoires of resistance are "situated in a certain time, space, and it engages with different (types of) actors, techniques" and power relations (Johansson \& Vinthagen, 2016, p 418). Primarily, identity politics are negotiated on social media through (1) cultural resistance (e.g., traditional song, food event; (2) mediated visibility as a politics (e.g., photography practice, hashtag), and (3) information resistance (e.g., diasporic media). Such techniques of resistance can be regarded as 'repressive and productive' (Foucault 1978) as well as the politics of 'confrontation and recognition' (Abraham \& Jaehn, 2019).

This paper shows how social media play a dual role of opportunities and risks simultaneously enabling both resistance and fear in everyday use through the presences, assemblages and absences of technologies. This paper argues that social media offer a niche of a repertoire of resistance and the rise of a new form of engagement as a transnational space in a context of surveillance and statelessness. Overall, by focusing on both urban and refugee camp settings, this paper responds to calls for more research into power inequalities and transnational diaspora activism, authoritarian politics, specifically its mediation by digital technologies.

\section{References}


Abraham, I., \& Jaehn, M. (2019). Immanent Nation: The Rohingya quest for international recognition. Nations and Nationalism.

Al-Rawi, A. (2019). Twitter Influentials and the Networked Publics' Engagement with the Rohingya Crisis in Arabic and English. The SAGE Handbook of Media and Migration, 192.

Alencar, A., Kondova, K., \& Ribbens, W. (2019). The smartphone as a lifeline: An exploration of refugees' use of mobile communication technologies during their flight. Media, Culture \& Society, 41(6), 828-844.

Amelina, A., \& Faist, T. (2012). De-naturalizing the national in research methodologies: Key concepts of transnational studies in migration. Ethnic and Racial Studies, 35(10), 17071724.

Anderson, B. (2006). Imagined communities: Reflections on the origin and spread of nationalism (Revised ed.): Verso books.

Appadurai, A. (1996). Modernity al large: cultural dimensions of globalization (Vol. 1): U of Minnesota Press.

Bernal, V. (2014). Nation as network: Diaspora, cyberspace, and citizenship: University of Chicago Press.

Brinkerhoff, J. M. (2009). Digital Diasporas: Identity and Transnational Engagement: Cambridge University Press.

Cohen, R. (2008). Global diasporas: An introduction (Second ed.): Routledge.

Foucault, M. (1978). The history of sexuality: An introduction (Vol. 1). New York: Random House.

Georgiou, M. (2006). Diaspora, identity and the media: diasporic transnationalism and mediated spatialities. Cresskill, N.J., United States.: Hampton Press.

Georgiou, M. (2019). Diaspora and the Plurality of Its Cosmopolitan Imaginaries. In J. Retis, \& Tsagarousianou, R. (Ed.), The Handbook of Diasporas, Media, Culture (pp. 63-76): John Wiley \& Sons, Incorporated.

Goffman, E. (1959). The Presentation of Self in Everyday Life. Garden City, NY: Doubleday.

Hall, S. (1990). Cultural Identity and Diaspora In J. Rutherford (Ed.), Identity: Community, Culture, Difference (pp. 222-239). London: Lawrence and Wishart

Johansson, A., \& Vinthagen, S. (2016). Dimensions of everyday resistance: An analytical framework. Critical Sociology, 42(3), 417-435.

Kaufmann, K. (2018). Navigating a new life: Syrian refugees and their smartphones in Vienna. Information, Communication Society, 21(6), 882-898.

Kvale, S., \& Brinkmann, S. (2009). Interviews: Learning the craft of qualitative research interviewing: Sage. 
Leurs, K., \& Smets, K. (2018). Five questions for digital migration studies: Learning from digital connectivity and forced migration in (to) Europe. Social Media+ Society, 4(1), 2056305118764425.

Marcus, G. E. (1995). Ethnography in/of the world system: The emergence of multi-sited ethnography. Annual review of anthropology, 24(1), 95-117.

Ponzanesi, S. (2020). Digital Diasporas: Postcoloniality, Media and Affect. Interventions, 1-17.

Robards, B., \& Lincoln, S. (2019). Social Media Scroll Back Method. In Sage Research Methods: SAGE Publications Ltd.

Robertson, Z., Wilding, R., \& Gifford, S. (2016). Mediating the family imaginary: Young people negotiating absence in transnational refugee families. Global Networks, 16(2), 219-236.

Scott, J. C. (1985). Weapons of the Weak. New Haven, CT: Yale University Press. 